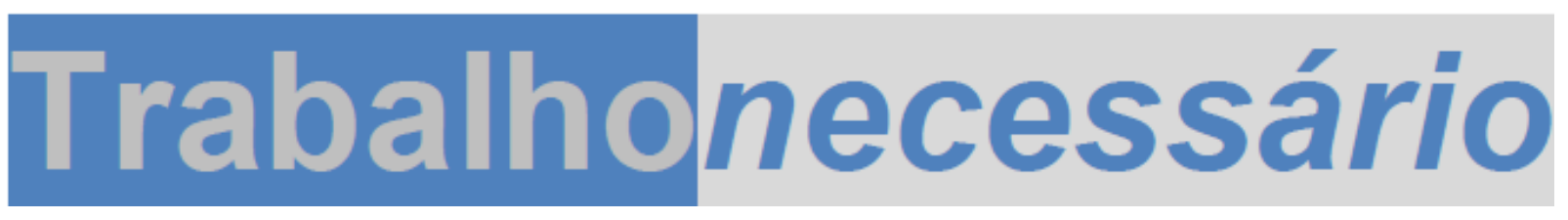

Issn: 1808 - 799X

ano 11, no $16-2013$

\title{
CIDADE MARAVILHOSA... PARA O CAPITAL: A PRODUÇÃO DO ESPAÇO URBANO E OS MEGAEVENTOS ESPORTIVOS NO RIO DE JANEIRO
}

\author{
Bruno Gawryszewski ${ }^{1}$
}

\begin{abstract}
Resumo: a cidade do Rio de Janeiro está sob as luzes dos holofotes, por conta da realização dos megaeventos esportivos. Essa condição tem justificado que o poder público invista numa grande reestruturação do espaço urbano, de modo a ressaltar virtudes a serem utilizadas como peça publicitária, a fim de tornar a cidade uma mercadoria atrativa para ser vendida para os altos empreendimentos do capital. $O$ processo em vigência tem se materializado na entrega de bens públicos para apropriação de empresas privadas pelo Estado, que tem atuado no sentido de exercer um estrito controle social nas ruas para afastar os sujeitos indesejados, remoção de comunidades em terrenos valiosos para a especulação imobiliária, promulgação de leis que asseguram a proteção ao capital e financiando a construção dos equipamentos esportivos, fazendo dos megaeventos esportivos um negócio com alta rentabilidade e tornando o Rio de Janeiro uma "cidade de exceção".
\end{abstract}

Palavras-chave: espaço urbano, megaeventos esportivos, capital.

Abstract: the city of Rio de Janeiro is under the lights of the spotlight, due to the realization of mega-sporting events. This condition has justified that the government invests in a major restructuring of urban space in order to emphasize virtues to be used as an advertising piece, in order to make the city an attractive commodity to be sold to the high capital ventures. The process in effect has materialized in the delivery of public goods to private ownership of the state, which has served to exert a strict social control in the streets to ward off unwanted subjects, removal of communities in land for valuable land speculation, enactment of laws that ensure protection to capital and financing the construction of sports

\footnotetext{
1 Doutorando pelo PPGE-UFRJ e integrante do Coletivo de Estudos em Marxismo e Educação (COLEMARX). E-mail: brunog81@yahoo.com.br
} 


\section{Trabalhonecessário}

Issn: 1808 - 799X

ano 11, no $16-2013$

stadiums, doing a business of mega-sporting events with high profitability and making the Rio de Janeiro a "city of exception."

Keywords: urban, mega-sporting events, capital.

Desde o fim da década de 1990, os governos locais tem realizado esforço considerável para projetar a cidade do Rio de Janeiro no cenário global, a fim de se constituir em destino privilegiado dos investimentos do capital.

A partir de uma aliança entre gestores públicos, corporações locais e grande imprensa, conforma-se um campo de interesses econômicos que, consquentemente, formula um marco discursivo a fim de tornar a cidade como algo "vendável", uma cidade-mercadoria que integra a racionalidade capitalista de transformar os elementos da vida em valor de troca.

A cidade passa a ser objeto de peça publicitária que se enquadra a um determinado modelo que lhe torne mais atrativa, modelo este que coincide com determinados centros de pensamento de produção do espaço urbano: instituições multilaterais como o Banco Mundial e seus congêneres; blocos regionais como a União Europeia; grandes escritórios e fundações dedicadas a projetos de arquitetura e urbanismo; e ideólogos destinados a cumprir o papel de propagadores da ideologia da globalização e do neoliberalismo. Por meio de análise sobre alguns processos de reestruturação urbana na década de 1990, Sánchez (2001, p. 33) detectou convergências nas estratégias utilizadas pelo poder político para vender as cidades ${ }^{2}$. Segundo a autora, essa estratégia global envolve:

a construção da cidade-mercadoria que, sob a égide do poder político dos governos locais, perfila-se através dos processos de reestruturação urbana (como exigência da economia competitiva) e através da construção de imagem para vendê-la, para inseri-la

\footnotetext{
${ }^{2}$ A autora cita as cidades de Curitiba, Barcelona, Montpellier, Lille, Nantes, Oxford, Manchester, Chicago, Boston e Baltimore.
}

TrabalhoNecessário - www.uff.br/trabalhonecessario; Ano 11, № 16/2013. 


\section{Trabalhonecessário}

Issn: 1808 - 799X

ano 11, no $16-2013$

no mercado. Como mercadoria especial, envolve estratégias especiais de promoção: são produzidas representações que obedecem a uma determinada visão de mundo, são construídas imagens-síntese sobre a cidade e são criados discursos referentes à cidade, encontrando na mídia e nas políticas de city marketing importantes instrumentos de difusão e afirmação.

Tomando como comparação a cidade brasileira mencionada, Curitiba, se, por um lado, é possível afirmar que ainda não se consolidou essa imagem de cidade-modelo para o Rio de Janeiro, percebe-se um esforço recorrente de apresentar a cidade como se estivesse em reestruturação urbana em prol de torná-la eficiente e sustentável, aliado ao patrimônio natural e paisagístico que a torna distinta das grandes metrópoles mundiais, valor simbólico que se sobressai como atividade de representação imagética ${ }^{3}$.

No entanto, não se pode deixar de considerar que essas representações do espaço se relacionam com as condições políticas do tempo presente e, nesse sentido, Sánchez (2001, p. 41) aponta que as intervenções nas cidades:

[...] parece indicar a emergência de um conjunto de representações que desenham uma cidade ideal, fruto de uma competição imagética, de uma luta simbólica que procura dotar esta cidade ideal das quantidades apropriadas de valores hegemônicos.

E quais seriam os valores contidos nessa competição? As intervenções urbanas no Rio de Janeiro não indicam que estejam a serviço da integração social e da promoção da dignidade humana, pois em muitos casos, como será abordado adiante, a marca que salta aos olhos é a preocupação em viabilizar as melhores condições possíveis para os investidores privados, independente dos danos causados à população, particularmente aquela parcela mais despossuída de recursos materiais e simbólicos de lutar contra 0 poder colossal dos representantes do capital.

\footnotetext{
${ }^{3}$ Pode-se conferir essas representações imagéticas nos filmes publicitários para promover os Jogos Olímpicos de 2016. http://www.youtube.com/watch?v=Uk0vHXFwdjI http://www.youtube.com/watch?v=UdmgHnqxyBo\&feature=related, acesso em 22 out. 2012
} 


\section{Trabalhonecessário}

Issn: 1808 - 799X

ano 11, no $16-2013$

Não é nenhuma novidade que a reestruturação urbana e a produção do espaço sejam utilizadas como forma de absorver os excedentes de capital que não estejam alocados no processo de circulação para reproduzir seu valor. E esse processo é contínuo, visto que o capitalismo é um modo de produção que se destina perpetuamente à produção de excedentes e a urbanização surge como uma alternativa para remediar essa questão. Paris se tornou a "cidade-luz" muito por conta do programa de obras públicas conduzido pelo Barão Haussmann em meados do século XIX que, segundo Harvey (2011, p. 138),

\footnotetext{
Haussmann entendeu claramente que sua missão era ajudar a resolver o problema do capital e mão de obra excedentes por meio de urbanização. A reconstrução de Paris absorveu enormes quantidades de trabalho e de capital para os padrões da época e, juntamente com o autoritarismo, acabou com as aspirações dos trabalhadores de Paris e foi um importante veículo de estabilização social.
}

O geógrafo estadunidense também cita o exemplo de Nova York no pós-2a guerra mundial, conjuntura em que havia um enorme excedente de capital e a "ameaça comunista" rondando o país. Então o engenheiro Robert Moses conduziu o programa de reestruturação urbana da cidade que acabou se expandindo para boa parte do país, em que promoveu o sistema de rodovias e utilização do automóvel como meio de deslocamento e a suburbanização de vastas áreas.

Desde a crise do capital da década de 1970, há cada vez menos territórios e espaços livres que ainda não foram tomados pelo investimento direto do capital. A produção de novos espaços urbanos absorvem grandes quantidades de excedentes de capital e a mudança na configuração das cidades acaba representando uma possibilidade de reprodução. E pode-se dizer que a escolha desses espaços a ser contemplados com esses investimentos não denotam de nenhum processo randômico, ao contrário, eles decorrem de processos de 


\section{Trabalhonecessário}

Issn: 1808 - 799X

ano 11, no $16-2013$

acumulação inseridos em contextos macro, relacionados a uma "teoria do desenvolvimento geográfico desigual do capitalismo" (HARVEY, 2011).

A crise na reprodução do capital que tem assolado a Europa e os Estados Unidos vem redirecionando o destino dos excedentes. O Brasil, particularmente, $\mathrm{O}$ estado do Rio de Janeiro se converteu num grande polo de atração para os investidores nacionais e multinacionais. Em 2010, a cidade recebeu US $\$ 18,45$ bilhões, muito por conta das recentes descobertas na camada do pré-sal, a construção do polo petroquímico do Comperj e toda cadeia de setores variados da indústria como construção naval e siderurgia ${ }^{4}$.

Esse afluxo de capitais também tem sido, em boa medida, direcionado pelo poder público na apropriação de patrimônios públicos pela iniciativa privada, sob o pretexto de dinamizar a economia e conferir mais apelo turístico a essas áreas. Um exemplo que confirma essa opção é a Marina da Glória, que foi arrendada pelo grupo EBX, a fim de construir um conjunto arquitetônico, contendo um prédio de 15 metros de altura, uma garagem subterrânea e um píer, projeto que terminou engavetado por conta dos altos custos que teriam de ser investidos pela corporação, além dos protestos de associação de moradores. Ainda assim, como detentor dos direitos de exploração comercial do espaço, situado no parque público do Aterro do Flamengo, a empresa vem explorando comercialmente o local através de diversos eventos que nada tem de caráter público e tem bloqueado o acesso em diversos pontos para usufruto dos pedestres que circulam pelo local.

\footnotetext{
${ }^{4}$ Alguns exemplos: Em São João da Barra, a LLX (empresa do conglomerado EBX de Eike Batista) está construindo o Porto do Açu. Em Itatiaia, a Michelin investe na construção de uma fábrica de pneus e a Procter \& Gamble está ampliando o seu centro de distribuição de mercadorias. Em Angra dos Reis, a Technip está investindo US\$ 700 milhões na ampliação do porto da cidade. O Parque Tecnológico da UFRJ promoveu licitação dos últimos terrenos disponíveis para a instalação de empresas multinacionais, além do grande loteamento do terreno pela Petrobrás. Informações disponíveis em OLIVEIRA, Eliane; ROSA, Bruno. Um Rio de negócios, O Globo, Economia, p. 27, 11 set. 2011.
} 


\section{Trabalhonecessário}

Issn: 1808 - 799X

ano 11, no $16-2013$

Dentre os diversos projetos comandados pela atual gestão do Prefeito Eduardo Paes (PMDB) chama a atenção o projeto para a região do Porto, denominado Porto Maravilha. O projeto nasceu fruto do Decreto Municipal 101/2009, que modifica o Plano Diretor da Cidade e autoriza a instituição da Operação Urbana Consorciada da região do Porto do Rio, a fim de que se institua uma reestruturação urbana, inclusive com a modificação do gabarito para a região, permitindo a construção de prédios com até 50 andares. Um dos maiores investimentos trata-se do complexo empresarial "Porto Atlântico", que incluirá salas comerciais de alto padrão, hotéis de bandeira internacional e uma série de serviços articulados a essa cadeia econômica.

A partir de 2011, as obras estruturais e os serviços de zelo público, como coleta de lixo, limpeza urbana, iluminação, manutenção de ruas e calçadas e operação do tráfego, foi concessionado a Porto Novo - consórcio formado pelas empresas Odebrecht, OAS e Carioca Engenharia - por 15 anos, junto com a Companhia de Desenvolvimento Urbano da Região do Porto (CDURP), naquela que vem sendo chamada de "a maior parceria público-privada do país", a fim de administrar uma área de 5 milhões de metros quadrados.

A lista das obras é tão extensa que é inviável que se reproduza aqui, mas destacam-se a demolição da via do Elevado da Perimetral e a consequente transformação da Avenida Rodrigues Alves em via expressa, a construção de dois museus, o Museu do Amanhã e o Museu de Arte do Rio (MAR), abertura de 4 túneis e toda uma série de obras na rede de esgoto, ampliação da área verde e nos sistemas de transporte. Sobre o último, além das intervenções já mencionadas, também está incluída a implantação do Veículo Leve sobre Trilhos (VLT) que circulará pela Zona Portuária e Centro.

No que tange ao sistema de transporte, a Prefeitura como parte auxiliar que concede a licença para operação das linhas de ônibus na cidade, mantém intacto o oligopólio formado por um pequeno pool de empresas que comanda 


\section{Trabalhonecessário}

Issn: 1808 - 799X

ano 11, no $16-2013$

diversas subsidiárias. A realização da primeira licitação pública em 2010 não atenuou o fato de que se tem privilegiado aos mesmos grupos que operam sem oferecer condições dignas aos passageiros por meio de tarifas escorchantes cobradas aos passageiros. E há uma denúncia do Tribunal de Contas do Município que identificou indícios de formação de cartel e irregularidades no processo licitatório. Além disso, o pacote de benesses da Prefeitura incluiu a redução do ISS para que essas empresas paguem somente o valor de $0,1 \%$.

Outra "menina dos olhos" de Eduardo Paes é a implantação do sistema BRT (Bus Rapid Transit). Os BRTs são ônibus com capacidade para transportar até 160 passageiros, articulados em dois carros. Eles possuem corredores exclusivos para transitar de forma mais ligeira e estações fechadas. Os quatro corredores expressos, todos denominados pelo prefixo Trans, são: Transoeste (Barra da Tijuca-Santa Cruz e Campo Grande), Transcarioca (Barra da TijucaAeroporto Galeão), Transolímpica (Barra da Tijuca-Deodoro) e Transbrasil (Avenida Brasil-Aeroporto Santos Dumont). Destas, apenas a Transoeste já foi parcialmente inaugurada, mas chama a atenção que o destino converge inevitavelmente à Barra da Tijuca e aos aeroportos do Rio de Janeiro, o que se evidencia os interesses econômicos envolvidos nesses grandes empreendimentos.

As autopistas mantém o modelo rodoviarista para a cidade do Rio de Janeiro que privilegia tanto o transporte de médio porte como o dos ônibus, quanto 0 individual, efetuado pelos carros. Além de remover diversas comunidades em quantias que muitas vezes sequer atendem aos valores de mercado, a via expressa não previu melhorias nos locais que concentram a parcela da população pobre que se deslocará de ônibus para o seu trabalho, apenas viabilizou que pudessem chegar mais rápido, mantendo-os nos locais com pior infraestrutura local. Ou seja, transporta-se a mão de obra barata mais rápida, sem tocar nos problemas decorrentes da periferização da cidade.

TrabalhoNecessário - www.uff.br/trabalhonecessario; Ano 11, № 16/2013. 


\section{Trabalhonecessário}

Issn: 1808 - 799X

ano 11, no $16-2013$

Esse terreno regido por interesses econômicos e que marca a cidade como protagonista de uma peça publicitária, adquiriu na década de 2000 uma expressiva importância, vide a grande ênfase que o poder público conferiu a campanhas, como o concurso promovido por uma fundação internacional para escolher as sete maravilhas do mundo moderno, no intuito de agregar valor à cidade e sustentar uma integração social entre os seus cidadãos. Um segundo capítulo escrito recente foi a conquista do título para a cidade de Patrimônio Cultural como paisagem cultural urbana concedido pela Unesco.

Essa produção do espaço urbano constitui um conjunto de medidas parte de uma construção ideológica de afirmar a cidade como um território privilegiado a receber os investimentos mais polpudos, uma cidade que angaria adesão de parte da opinião pública, a fim de generalizar um consenso como estratégia local para se inserir nos padrões de competitividade de se vender como mercadoria.

Ainda que o consenso surja como a forma de operar as intervenções urbanas, é coerente com o referencial teórico-metodológico deste trabalho que a adesão e o convencimento não se tornem estanques do aspecto coercitivo, ou seja, aquilo que parece a primeira vista como persuasão também pode ter uma boa dose de violência, abuso e mesmo a quebra da ordem liberal-democrática como instituída em nossa sociedade. Quando a Prefeitura altera por decreto-lei os parâmetros urbanísticos da cidade em favor da construção de prédios com gabarito liberado, arrenda áreas e parques públicos em prol da administração de um grupo empresarial ou permite a construção de determinados empreendimentos em áreas protegidas por legislação ambiental, ela não o faz desprovido de interesse, mas movido pelo interesse privado, marca inescapável do Estado burguês. Por isso, o trabalho sustenta o entendimento de que o consenso também pode ser coercitivo e não meramente fruto de uma adesão idílica de sujeitos livres que optaram por determinado caminho. 


\section{Trabalhonecessário}

Issn: 1808 - 799X

ano 11, no $16-2013$

Porém, a reestruturação urbana também contém a dimensão da violência expressa da forma direta, sem mediações, através da ação de instrumentos de repressão como as remoções de favelas habitadas pela parcela mais despossuída de direitos, promovidas pelo poder público; os incêndios aleatórios e com indícios de intenção criminosa que amedrontam e provoca o êxodo de famílias; o poder judiciário que garante o direito de posse de terras e habitações a especuladores e emite ordem de despejos a trabalhadores, contrariando 0 princípio da função social da moradia. Existe um lado sombrio no processo de absorção do excedente do capital que contém uma dimensão de classe, pois são geralmente os pobres, os desfavorecidos e os marginalizados do poder político os que sofrem especialmente com esse processo.

Um exemplo notório que ocorre sistematicamente no Rio de Janeiro é a perseguição contra os camelôs que, excluídos do mercado formal de emprego, busca na venda de pequenas mercadorias o seu próprio sustento. Não é de hoje que essa camada da classe trabalhadora sofre com os desmandos e o autoritarismo incorporado pela Guarda Municipal, mas, particularmente, na gestão de Eduardo Paes, tais ações ganharam um teor de peça publicitária: as operações "Choque de Ordem". Coordenada pela Secretaria Especial da Ordem Pública, sua face mais conhecida são as operações tem se concentrado em proibir o comércio de produtos por ambulantes não cadastrados.

O "choque de ordem", expressão genérica e nem sempre realizada pela Guarda Municipal, tem sido marcado por outra ação: a do recolhimento compulsório de viciados em crack nas ruas. É de conhecimento público que o Rio de Janeiro tem diversos pontos de uso de crack pelas ruas, as cracolândias, algumas delas mais conhecidas como nas proximidades do Morro Santo Amaro (Catete) e nas favelas do Jacarezinho e Manguinhos. Essas três localidades foram alvo de ação comandada por forças de segurança do mais alto poder bélico, a fim de banir a venda a venda da droga e recolher os dependentes 


\section{Trabalhonecessário}

Issn: 1808 - 799X

ano 11, no $16-2013$

químicos a força para os abrigos, sob orientação do prefeito. O Morro Santo Amaro está ocupado desde o dia 18 de maio de 2012 por 150 integrantes da Força Nacional de Segurança, acompanhados de profissionais da Secretaria Municipal de Assistência Social (SMAS) e policiais das Delegacias de Proteção à Criança e o Adolescente (DPCA) e de Combate às Drogas e apoio da Unidade de Ordem Pública (UOP) da Guarda Municipal. Após 2 meses de ocupação, mais de 3.000 pessoas já tinham sido atendidos, compulsoriamente ou não.

No caso das favelas de Jacarezinho e Manguinhos, os atos de recolhimento das pessoas foram uma consequência da ocupação pelas forças policiais e do Exército na região, a fim de se implantar novas UPPs. Mais de dois mil homens, acompanhados de veículos blindados de apoio das Forças Armadas, estão designados para permanecerem na região e, dentre as orientações, atuar sobre os usuários.

A decisão pela internação compulsória mesmo para maiores de idade, emitida pelo Prefeito Eduardo Paes, tem sido bastante contestada por entidades e especialistas no assunto, porque esse seria o último recurso e em casos extremos, pois atentaria contra a autodeterminação dos sujeitos, prática que vem sendo cada vez mais rejeitadas, em consonância com a luta antimanicomial, além do questionamento contra a qualidade dos abrigos mantidos pela Prefeitura, ao invés do tratamento ser prestado pela rede pública de saúde, o SUS. Não é recente que os abrigos mantidos pela Prefeitura não desfrutam de boa fama por tratar bem seus pacientes e muitos destes preferem fugir a se manterem sob os cuidados do Estado. Até o presente momento, a Prefeitura oferece vagas em abrigos ditos especializados para tratamento em crack, vagas que são oferecidas 


\section{Trabalhonecessário}

Issn: 1808 - 799X

ano 11, no $16-2013$

por ONGs em convênio com a SMAS, muitas vezes marcadas por irregularidades 5 .

Essas são algumas amostras que tem vindo a tona nesse processo de requalificação urbana, que vem moldando a cidade numa mercadoria cada vez mais atraente aos olhos do grande capital, terra de oportunidades com retorno garantido dos investimentos, mas que, para isso, são "necessárias" certas medidas que viabilizem a valorização da região e ofereça situação de tranquilidade e livre de todos os seres indesejados. Ainda assim, a época que se espera de maior visibilidade para a cidade ainda está por vir - em breve - através da realização dos megaeventos esportivos, no caso, a Copa do Mundo de futebol em 2014 e os Jogos Olímpicos em 2016.

A recente inversão de capitais para as metrópoles, particularmente o Rio de Janeiro, foco deste estudo, estão materializadas nas orientações governamentais em subsidiar grandes parcerias público-privadas por meio do BNDES e pelo esforço do poder público em promover os chamados megaeventos.

A luta incessante em receber os grandes complexos industriais e em realizar os megaeventos tem se constituído numa bandeira dos governos e setores empresariais ao assumirem como marco discursivo, dotado de um caráter indutor que, ao promover significativas obras de transformações estruturais urbanas, incentivos fiscais e mudanças na legislação tributária e ambiental, deixariam um legado à população local. Por isso, como tenho insistido, esses investimentos capitalistas estão diretamente associados a um projeto de produção do espaço urbano que visa posicionar as cidades / países sedes como territórios propensos a atrair grande fluxo de capitais.

\footnotetext{
5 ONG que mantém abrigo contra crack não pode renovar contrato. O Globo online, disponível em http://oglobo.globo.com/rio/ong-que-mantem-abrigo-contra-crack-nao-pode-renovar-contrato-6535598, acesso em 26 out. 2012.
}

TrabalhoNecessário - www.uff.br/trabalhonecessario; Ano 11, № 16/2013. 


\section{Trabalhonecessário}

Issn: 1808 - 799X

ano 11, no $16-2013$

Name, Gomes e Montezuma (2010) indicam que o Rio de Janeiro, desde 1993, quando César Maia assumiu a prefeitura local, deu uma guinada para se estabelecer como um modelo de cidade "mercadófila", favorecendo arranjos institucionais e jurídico-políticos para promover os interesses da iniciativa privada, especialmente pela implementação de vantagens comparativas para assegurar uma boa posição no quadro da divisão internacional do trabalho. Concordando com os autores supracitados, a chegada ao governo municipal por Eduardo Paes, viabilizou de modo ainda mais acelerado o projeto empresarial para a cidade, por conta do alinhamento político nas três esferas de governo. Assim, particularmente os megaeventos esportivos são postos na linha de frente para justificar quaisquer medidas de reestruturação urbana para legitimar a viabilização desses eventos, ainda que estejam sob intensas críticas por conta de um insuportável adensamento urbano em áreas despossuídas de infraestrutura básica e desfavorável do ponto de vista geobiofísico.

Faz-se a ressalva de que, para compreender o lugar que os megaeventos ocupam como indutores de tantas intervenções por parte dos governos e da iniciativa privada no espaço urbano e nos serviços para a população, é preciso que seja objeto de estudo da economia política do esporte.

A atual fase de mundialização do capital e suas medidas mais proeminentes como a liberalização da concorrência, a desregulamentação do trabalho assalariado e a financeirização da economia vêm atuando em configurar novas relações sociais e econômicas no campo esportivo. $O$ modelo de organização esportiva abriu espaço para que agentes privados controlem a organização dos torneios e a gestão de equipes. A entrada da lógica empresarial no comando do esporte, especialmente a associação entre ações de marketing e contabilidade como grande empresa, apresenta uma nova configuração para a continuidade do esporte.

TrabalhoNecessário - www.uff.br/trabalhonecessario; Ano 11, № 16/2013. 


\section{Trabalhonecessário}

Issn: 1808 - 799X

ano 11, no $16-2013$

As cifras que movimentam essa indústria são cada vez mais voluptuosas e a viabilização da indústria do esporte tem nos megaeventos esportivos o seu produto final. $\mathrm{O}$ aparato montado em torno desses eventos envolve diversos sujeitos sociais como governos, mídia, empresas, cidadãos, turistas e associações esportivas, o que, por sua vez, envolve diversos interesses de poder como a escolha da sede, um rol de contratos com patrocinadores e os direitos de transmissão.

Diante de tantos suportes financeiros aos megaeventos, percebe-se o poderio das entidades internacionais pelos seus balanços financeiros. No caso dos Jogos Olímpicos de Londres em 2012, a arrecadação do Comitê Olímpico Internacional pela cessão dos direitos de transmissão, pagamento dos patrocinadores master e local, venda de ingressos e licenciamento de produtos foi em torno de US $\$ 7$ bilhões $^{6}$. Já a FIFA, entidade máxima do futebol, apresentou um balanço dando conta de arrecadação de mais de US\$ 1 bilhão no ano de 2011 , totalizando um saldo positivo de US\$36 milhões e ainda contaria com uma poupança no valor de US $\$ 1,3$ bilhões ${ }^{7}$.

Ao ostentar cifras financeiras tão vultosas, é que se torna imprescindível discutir os nexos existentes entre o processo de reprodução do capital em meio a crises de sobreacumulação e a realização de megaeventos esportivos na nova geografia mundial. Para tanto, parto do legado de Lênin na análise sobre o imperialismo. A obra, escrita na véspera da revolução social do proletariado russo de 1917, oferece uma análise precisa quanto ao estágio em que o capitalismo se encontrava, de sua passagem de capitalismo concorrencial a um capitalismo monopolista, que, organizado em trusts e cartéis, levou adiante a partilha

\footnotetext{
${ }^{6}$ MIRÀS, Denise. Ciclo Olímpico fechado em Londres rende R\$ 16 bilhões ao COI, um recorde na história das Olimpíadas. R7, disponível em http://rederecord.r7.com/londres-2012/noticias/ciclo-olimpico-fechadoem-londres-rende-r-16-bilhoes-ao-coi-um-recorde-na-historia-das-olimpiadas/, acesso em 26 out. 2012.

7 HOMEWOOD, Brian. Fifa tem lucro de US\$ 36 milhões em 2011. Estadão, disponível em http://www.estadao.com.br/noticias/esportes, fifa-tem-lucro-de-us-36-milhoes-em-2011,855637,0.htm, acesso em 26 out. 2012.
}

TrabalhoNecessário - www.uff.br/trabalhonecessario; Ano 11, № 16/2013. 


\section{Trabalhonecessário}

Issn: 1808 - 799X

ano 11, no $16-2013$

conflituosa do mundo entre associações capitalistas e um seleto grupo de nações hegemônicas e que teve como desfecho a I Guerra Mundial (1914-18).

Um dos pontos assinalados por Lênin é que a exportação de capital seria a característica fundamental do capitalismo moderno, ao contrário do velho capitalismo em que predominava a livre concorrência. No curso do desenvolvimento do capitalismo ao longo do século XIX e início do século $X X$ foram forjadas uniões monopolistas de países de capitalismo desenvolvido e, posteriormente, nos países que tinham alcançado proporções voluptuosas de acumulação de capital, o que resultou num enorme excedente que precisava ser investido em terras alheias.

$\mathrm{Na}$ linha deste debate, o geógrafo estadunidense David Harvey (2005) propõe a teoria da ordenação espaço-temporal como maneira de explicar a sobrevivência do capitalismo em meio a crises de excedentes de capitais. $O$ autor procura mostrar como as classes dominantes manejam a gestão dessas crises do capital por meio do adiamento do tempo e da expansão geográfica para impedir o ascenso do movimento organizado dos trabalhadores.

Na medida em que há uma situação de excedentes de capital, esses ativos represados tendem a se desvalorizar ou serem destruídos a fim de evitar uma redução ainda maior de seu valor. Desse modo, a expansão geográfica e a reorganização espacial proporcionam a opção para sua realização valorativa. Essa expansão geográfica geralmente envolve mudanças de localização que, movido por um impulso de redução ou eliminação das barreiras espaciais, acelera a taxa de giro do capital, evitando assim seu represamento.

Entretanto, como atenta Harvey (2005, p.78)

Não é, contudo, possível divorciar essa opção de mudanças temporais em que o capital excedente é deslocado para projetos de longo prazo que precisam de muitos anos para devolver seu valor à circulação mediante a atividade produtiva que sustentam. 


\section{Trabalhonecessário}

Issn: 1808 - 799X

ano 11, no $16-2013$

Por isso, essa expansão geográfica envolve investimento em infraestruturas físicas de longo termo. A instalação dessas infraestruturas se constitui em capital fixo incorporado a terra, o que requer que as intervenções no espaço sigam um padrão geográfico que interajam entre si para que seu próprio valor se realize.

A ordenação espaço-temporal pode decorrer de uma combinação de deslocamento temporal mediante investimentos em projetos de capital de longo prazo e gastos sociais com deslocamentos espaciais por meio da abertura de novos mercados, novos recursos naturais e de trabalho. Conforme explica Harvey (idem, p. 94)

Os fluxos de capital são retirados do domínio da produção e do consumo imediatos (o circuito primário) e redirigidos seja para um circuito secundário de capital fixo e de formação de fundo de consumo ou para um circuito terciário de gastos sociais e de pesquisa e desenvolvimento. Os circuitos secundário e terciário absorvem o capital excedente em investimentos de longa duração.

A essa altura, o excedente de capital pode ser "reciclado" e voltar ao circuito primário, até que haja uma nova necessidade de investimentos em infraestruturas físicas e sociais. Esses investimentos aliviam, por um tempo, o problema da sobreacumulação às custas de uma concorrência em que os capitalistas buscam obter vantagens competitivas no interior dessa estrutura espacial, tendendo a ser atraídos ou impelidos a mudar para os locais em que os custos sejam menores ou as taxas de lucro maiores.

A migração dos megaeventos esportivos para os países ditos "emergentes" ou "em desenvolvimento" constitui-se como uma medida particular que atende ao funcionamento do sistema capitalista, sobretudo em momentos de crise. Uma das formas de enfrentamento de suas próprias crises é a criação de novos mercados, que possam absorver uma parte do excedente de riquezas por eles produzida, fazendo o deslocamento de grandes massas de capitais excedentes de setores 


\section{Trabalhonecessário}

Issn: 1808 - 799X

ano 11, no $16-2013$

primário e secundário que, sem perspectivas de investimentos lucrativos, migram para os serviços e operações financeiras (PENNA, 2010). Conforme Marx e Engels já demostraram, o lucro do capital está na possibilidade de expropriação que o mesmo promove sobre o trabalho vivo. Daí o capital precisa criar maneiras de romper as fronteiras de Estados nacionais na busca por condições mais favoráveis à sua reprodução. E por que o deslocamento aos países "emergentes / em desenvolvimento"? Porque além de aliviarem o problema da sobreacumulação, proporcionam que os capitalistas obtenham vantagens comparativas no interior de estruturas econômicas em que as taxas de lucro são maiores por conta da expropriação contínua do excedente local produzido pelos trabalhadores.

Ao nos determos sobre o mapa geográfico dos dois maiores eventos esportivos em escala mundial, evidencia-se a preponderância desses países a partir da década de 2000, período em que países como Brasil, China, África do Sul e Rússia foram escolhidos para sediar a Copa do Mundo de Futebol e os Jogos Olímpicos.

A consecução desses eventos no país se realiza com a participação maciça do Estado. A cada megaevento, o Estado burguês ratifica a sua condição de classe, no intuito de abrir caminhos para os interesses privados, porém, estes eventos são vendidos como panaceias que resolverão todos os problemas de infraestrutura das cidades que acolherão as disputas. A realização de megaeventos esportivos se encontra enredada neste circuito do capital e os Jogos Pan-Americanos de 2007 no Rio de Janeiro, constituiu-se no marco inicial que, concretiza na realização dos eventos, chamarizes para consolidar certas frações burguesas, especialmente as que lidam com turismo, hotelaria, especulação imobiliária, construção civil e transporte urbano.

Em 2002, na época de candidatura para o Pan-2007, o grupo formado pelo Comitê Olímpico Brasileiro e as esferas do poder público fomentaram um 


\section{Trabalhonecessário}

Issn: 1808 - 799X

ano 11, no $16-2013$

ufanismo de que a cidade passaria por grandes mudanças estruturais em benefício dos cidadãos, o que incluía novas linhas de transporte aquaviário, expansão do metrô até a Barra da Tijuca e construção de nova linha que articularia os dois aeroportos da cidade, duplicação da autoestrada Lagoa-Barra, despoluição de lagoas e da Baía de Guanabara, dentre outros. É sabido que essas promessas não se concretizaram e, no plano imediato, frustrou as expectativas dos cidadãos cariocas que não desfrutaram de melhorias concretas em urbanização e, talvez, até setores empresariais ávidos em ganhar licitações para construção de grandes obras públicas. Contudo, ainda que nem todas as obras tenham se concretizado, é possível apontar como a ordenação espaçotemporal se realizou pela alocação dos excedentes do capital para sua valorização é contemplado por meio de diferentes mediações, como a cessão de uso da terra, aumento do gabarito de construções nas imediações ou exploração comercial do patrimônio público por meio de empresas privadas. Essas medidas se enquadrariam naquilo que David Harvey vem denominando como "acumulação por espoliação".

A tentativa de Harvey é de atualizar a categoria marxista da acumulação primitiva, que se manifestava através da privatização da terra, da expulsão violenta dos camponeses, da escravidão, da usura, dentre outros. Tais mecanismos de acumulação espúria persistem, tais como as fraudes no sistema financeiro, a pilhagem de recursos naturais, os direitos de propriedade intelectual e os tratados de livre comércio (HARVEY, 2005). Diferente da acumulação primitiva, essa relação de dominação não se vale exclusivamente de ações coercitivas, procurando se combinar a elementos de consenso, através de cooptação ou de convencimento, para legitimar a apropriação privada dos ativos extraídos da riqueza socialmente produzida. Por isso, compreendemos que a acumulação por espoliação é uma condição para que o capital se aposse e libere 


\section{Trabalhonecessário}

Issn: 1808 - 799X

ano 11, no $16-2013$

um conjunto de ativos ainda não introduzidos no circuito de reprodução econômica.

A acumulação por espoliação interfere positivamente no problema dos excedentes de capital, pois encontra destinos para sua realização lucrativa. Nesse sentido, o Estado desempenha um papel imprescindível, na medida em que intervém para regular os salários, coordena a liberação de ativos, como as privatizações de empresas públicas e os tratados de livre comércio e ainda tem o poder de orquestrar desvalorizações para permitir que a acumulação ocorra sem desencadear um colapso geral, propiciando o cenário perfeito para a concretização sua missão "salvacionista" em resgatar setores inteiros da economia. E no contexto do presente trabalho, cabe recordar a intensa participação dos governos locais e nacionais na busca pelo direito de sediar os megaeventos esportivos. É possível citar alguns exemplos ocorridos nos Jogos de 2007, especialmente o fervor da especulação imobiliária no entorno da Barra da Tijuca e Recreio dos Bandeirantes, a construção da Vila Pan-Americana e do Estádio João Havelange.

Quando o projeto do Pan-2007 concentrou cerca de 70\% das competições nos bairros da Barra e Recreio, este se deu sob a alegação de que o deslocamento dos atletas seria facilitado pela proximidade entre as instalações e a acomodação e pela maior disponibilidade de terrenos. O que, do ponto de vista operacional parece natural, aponta para interesses privatistas da ordem de grandeza de bilhões de reais. O mercado imobiliário, que já atua com bastante voracidade nesta região da cidade, obteve uma intensa valorização em seus negócios. Foi formada uma espécie de "corredor pan-americano" na Avenida Abelardo Bueno, que abrigou o Parque Aquático Maria Lenk e a Arena Multiuso e é a via de acesso até as instalações do Riocentro, onde foram disputadas outras competições. A avenida foi contemplada com diversas obras como dragagem, duplicação da pista, reordenamento do tráfego e reurbanização paisagística na 


\section{Trabalhonecessário}

Issn: 1808 - 799X

ano 11, no 16 - 2013

via, sendo este último um investimento privado que foi batizado como Boulevard do Pan, o que representou um crescimento e valorização nas vendas de imóveis na região.

No que tange ao setor imobiliário, o caso mais emblemático foi a construção da Vila Pan-Americana. A construção, destinada a abrigar os atletas no período da competição, negociou os 1480 imóveis para compradores particulares. Celebrada como um grande sucesso de vendas por conta de ter vendido 1100 apartamentos em apenas um dia, o que a empreiteira Agenco e a imobiliária Patrimóvel não alardeiam é que os prédios foram construídos sob solo predominantemente hidromórfico, ou seja, possuidores de alta umidade subterrânea, solos mais apropriados a usos leves, como áreas de lazer e parques. O seu uso habitacional implicou num encarecimento da construção e permanente vistoria pelo uso inadequado do solo (MASCARENHAS, 2007). Além do mais, o conjunto habitacional foi viabilizado com apoio de recursos públicos do Fundo de Amparo ao Trabalhador, financiamento abaixo da média e aluguel para os atletas no valor de $\mathrm{R} \$ 1.137,00$ a diária. Numa manobra espúria, os recursos públicos foram apropriados para fins privados.

A construção do Estádio João Havelange (Engenhão) foi o elemento-chave para que a Prefeitura do Rio elaborasse e conseguisse a aprovação do projeto de lei 4125/05, que institui a Área de Especial Interesse Urbanístico do Engenho de Dentro, possibilitando mudança nos parâmetros urbanísticos da região. Permite, por exemplo, o aumento da construção de imóveis para até dezoito pavimentos, ou seja, liberando ativos para a especulação imobiliária.

Os próximos eventos que desembarcarão no país e, particularmente, no Rio de Janeiro prometem ser o marco definitivo dessa época de bonança e perdularismo. Os dados são bastante imprecisos, mas segundo apuração do Tribunal de Contas da União, os custos de realização da Copa do Mundo, evento a ser realizado em 12 sedes do território nacional, já ultrapassam todas as 


\section{Trabalhonecessário}

Issn: 1808 - 799X

ano 11, no $16-2013$

expectativas. Inicialmente, os gastos previstos giravam na ordem de $R \$ 17$ bilhões para reforma e construção dos estádios e investimentos em mobilidade urbana sem contar investimentos em segurança, promoção do turismo e infraestrutura das cidades. Contudo, no relatório divulgado pelo próprio Tribunal em junho de 2012, os custos teriam ultrapassado os $R \$ 27,4$ bilhões.

A maior parte dos recursos e financiada pelas empresas estatais, como BNDES, Caixa Econômica Federal e Infraero, diferente do discurso inicial que prometia que seria uma Copa do Mundo financiada sem dinheiro público. O alto custo e as incertezas de retorno em curto prazo por conta dos estádios pertencerem em sua maioria aos governos estaduais e municipais fizeram com que o governo federal adotasse uma linha de crédito de $R \$ 400$ milhões por estádio, a fim de se garantir reforma ou construção. Contudo, após a construção ou reforma concluída, o caminho que se aponta para a maioria dos 12 estádios é a concessão de sua administração para a iniciativa privada, seguindo a tônica de todas as privatizações realizadas no Brasil nas últimas duas décadas. $O$ complexo do Maracanã, que já consumiu mais de $\mathrm{R} \$ 1$ bilhão dos cofres públicos, foi objeto de um estudo de viabilização para privatização pela empresa IMX (de propriedade do empresário Eike Batista) e que indicou não só a "viabilidade" da privatização, mas como a demolição do parque aquático, do estádio de atletismo, da escola municipal Friedenreich e do centro cultural indígena Aldeia Maracanã para a construção da infraestrutura "necessária" para abrigar as competições esportivas da FIFA e do COI, como um museu do esporte e amplas áreas de estacionamento.

Em maio de 2013, o complexo do Maracanã passou pelo processo de licitação em que dois consórcios de megacorporações concorreram para obter a concessão de 35 anos, e o vencedor foi o "Consórcio Maracanã" liderado pela Odebrecht (90\% das ações), a AEG (5\%) e a própria IMX (5\%) que deverão repassar um valor de $R \$ 5$ milhões anuais, totalizando ao final do contrato a cifra 


\section{Trabalhonecessário}

Issn: 1808 - 799X

ano 11, no $16-2013$

de $R$ \$ 181,5 milhões, o que, ao final da concessão. Caso o grupo vencedor consiga explorar comercialmente o espaço com sucesso financeiro, pode-se concluir que o negócio promovido pelo Estado do Rio de Janeiro é quase uma doação aos investidores privados, tendo em vista que a estimativa é que os recursos investidos pelo consórcio vencedor sejam quitados em pouco mais de 10 anos.

A construção das instalações esportivas é um capítulo à parte na realização dos megaeventos esportivos, pois, além de cercadas de diversas suspeitas de irregularidades financeiras, entrega do patrimônio público a grupos privados e superexploração dos trabalhadores das obras, reside nesse fim uma dimensão fundamental do processo de reprodução do capital: a lógica da "produção destrutiva", entendendo-a como uma estratégia de aceleração da circulação e expansão do capital e, conseqüentemente, criadora de um número cada vez maior e diversificado de transações dentro do "próprio círculo de consumo". Este mecanismo, segundo Mészáros (2002, p. 680), além de promover novas margens de expansão do capital, produz, ainda, meios para seu fortalecimento frente às suas contradições imanentes. Tem o caráter destrutivo porque é uma "produção genuinamente orientada para o consumo destrutivo", neste caso, em particular, instalações esportivas que, após a realização do megaevento, não serão utilizadas com frequência que justifique sua manutenção a fim de fomentar o esporte e o uso social do espaço ${ }^{8}$.

Essa lógica, que agride os limites do razoável e se ampara no desperdício e na irracionalidade, tal como afirma Baran (1977, p. 75) constitui "formas sob as quais se esconde o excedente econômico potencial na complexa teia de aranha da economia capitalista". Nesse sentido, o desperdício de recursos determinado pela existência de monopólios e da competição monopolista relaciona-se à

\footnotetext{
${ }^{8}$ A discussão foi fruto de um artigo escrito com Adriana Penna (2009). Ver referências.
} 


\section{Trabalhonecessário}

Issn: 1808 - 799X

ano 11, no $16-2013$

própria essência do capitalismo, contribuindo para garantir a manutenção dos critérios de sobrevivência do capital, conforme afirma Mészáros (2002, p.678-9).

(...) tornou-se necessário adotar a forma mais radical de desperdício - isto é, a destruição direta de vastas quantidades de riqueza acumulada e de recurso elaborados - como maneira dominante de se livrar do excesso de capital superproduzido.

Os exemplos recentes que se enquadram nesse caso abundam. A manutenção de alguns dos estádios construídos para a Copa do Mundo realizada na África do Sul tem causado mal-estar, tendo em vista sua pouca utilização e custos muito acima do retorno financeiro ${ }^{9}$. Também o mesmo se passa com relação aos estádios erguidos ou reformados para a realização da Eurocopa2004, realizado em Portugal. Três estádios em cidades pequenas (Algarve, Aveiros e Leiria) sem equipes de futebol de ponta no país tem enfrentado uma série de dificuldades para manter esses "elefantes brancos"10.

O mesmo ocorreu no Brasil em função do Pan-2007, na cidade do Rio de Janeiro. Embora as arenas construídas para as competições não tenham sido literalmente demolidas até 0 momento, transformaram-se em estruturas obsoletas. Quando muito são entregues pelo poder público à iniciativa privada sob contratos de longa duração, a preços insignificantes, se avaliado o custo que essas mesmas instalações representaram ao orçamento público brasileiro.

A contradição, neste caso, é tamanha se tomarmos como exemplo o caso do estádio Delle Alpi, construído para a Copa da Itália em 1990, localizado em Turim. Após vinte anos de sua construção, está considerado obsoleto e disfuncional, por conta da distância entre o público e o campo causada pela pista de atletismo e foi demolido para que o clube construísse um estádio mais

\footnotetext{
${ }^{9}$ CHAYAMITI, Inara; BARBOSA, Mariana. Após dois anos, África do Sul ainda paga conta de estádios. Folha online, disponível em http://www1.folha.uol.com.br/multimidia/videocasts/1069576-apos-dois-anosafrica-do-sul-ainda-paga-conta-de-estadios.shtml, acesso em 31 out. 2012.

${ }^{10}$ Estádios do Euro: da glória à vergonha. Disponível em http://folhadeportugal.pt/?p=8828, acesso em 31 out. 2012.
}

TrabalhoNecessário - www.uff.br/trabalhonecessario; Ano 11, № 16/2013. 


\section{Trabalhonecessário}

Issn: 1808 - 799X

ano 11, no $16-2013$

moderno. Ou seja, o que é considerado obsoleto e disfuncional, foi utilizado como padrão para o Pan-2007 na construção do estádio "Engenhão".

Para a realização da Copa do Mundo em 2014, pelo menos quatro cidadessedes de jogos (Manaus, Natal, Brasília e Cuiabá) corre sério risco de ver seus estádios como símbolo da realização de um evento elitista e que não serve aos propósitos tão nobres e solidários ao qual se autointitula, visto que os estados não têm equipes participantes da principal divisão do campeonato brasileiro e mesmo sem o desenvolvimento local do futebol de alto rendimento que sustente tamanhos custos para sua manutenção.

No que diz respeito aos Jogos Olímpicos, o velódromo construído para o Pan-2007 será demolido porque estaria "fora dos padrões ${ }^{11}$ " para uma competição olímpica. O custo para construção do novo velódromo, arcado pelo Governo Federal, será de $R$ \$ 134 milhões, contra $R$ \$ 126 milhões estimados para a reforma. $\mathrm{O}$ atual foi erguido a um custo de $\mathrm{R} \$ 14$ milhões, em valores da época.

Desse modo, pode-se deduzir que tais estratégias têm servido mesmo é para perpetuar o ciclo de movimentação do capital em ritmo acelerado. O esporte, nesse sentido, vem servindo de ferramenta para minimizar as contradições e gerenciar as crises vividas pelo modo de produção capitalista. As cifras financeiras como já vimos giram na ordem de bilhões de dólares, portanto, os grupos capitalistas e as federações esportivas atuam no sentido de se associarem aos governos e elites locais a fim de moldar o país às necessidades e prerrogativas para os lucros privados. Um dos aspectos mais importantes é a reformulação ou promulgação de legislações especiais para o período de realização dos megaeventos.

\footnotetext{
${ }^{11}$ As alegações é que a pista não tinha a angulação adequada para competições de velocidade, arquibancada insuficiente para uma competição desse porte e colunas que impedem a visualização dos atletas pelos árbitros e câmeras de TV.
} 


\section{Trabalhonecessário}

Issn: 1808 - 799X

ano $11, \mathrm{n}=16-2013$

Essa dinâmica obriga que todos os países, quando se candidatam a receber algum megaevento esportivo, devem concordar a priori em criar legislações específicas a fim de atender aos interesses ditados pela federação esportiva, promotora e dona dos direitos da competição. Em muitos casos, a aprovação de uma lei específica fere a própria constituição nacional, ataca direitos dos trabalhadores e nada mais que promovem a privatização do evento para os oligopólios que o patrocinam. Por isso, esse corpo de leis vem sendo classificado como uma "legislação de exceção", na medida em que se processa à própria revelia dos ordenamentos jurídicos nacionais.

No centro desse processo, a Lei Geral da Copa (12663/2012) foi objeto de muita polêmica porque tem um escopo que atenta contra a soberania nacional, como o fato de que os consumidores que comprem ingresso terão automaticamente garantia de visto de entrada no país. Também a proteção à propriedade industrial e logomarcas é de uma ferocidade leonina, pois qualquer coisa, até itens de uso corriqueiro como o numeral 2014 ou o nome das cidadessede que façam referência à Copa do Mundo estão reservadas a uso da entidade máxima do futebol ${ }^{12}$. Outra decorrência importante da lei é a restrição e os condicionantes para ir e vir que se relacionem aos locais de competição, que será determinado pela entidade de futebol a um perímetro que pode chegar a $2 \mathrm{~km}$, o que implica na proibição de venda de qualquer mercadoria que não obtenham autorização da organização do evento. Por consequência, é fácil prever que a perseguição aos ambulantes será implacável durante o mês de duração da Copa do Mundo. E nas disposições finais, a "cereja do bolo", pois indica que a União

\footnotetext{
${ }^{12}$ Lei 12663, capítulo II, art $3^{\circ}$ : O Instituto Nacional da Propriedade Industrial (INPI) promoverá a anotação em seus cadastros do alto renome das marcas que consistam nos seguintes Símbolos Oficiais de titularidade da FIFA, nos termos e para os fins da proteção especial de que trata o art. 125 da Lei no $\underline{9.279}$, de 14 de maio de 1996: [...] IV - outros Símbolos Oficiais de titularidade da FIFA, indicados pela referida entidade em lista a ser protocolada no INPI, que poderá ser atualizada a qualquer tempo. Art $5^{\circ}, \S 1^{\circ}, \mathrm{I}$ - o INPI não requererá à FIFA a comprovação da condição de alto renome de suas marcas ou da caracterização de suas marcas como notoriamente conhecidas;
} 


\section{Trabalhonecessário}

Issn: 1808 - 799X

ano 11, no $16-2013$

responderá por qualquer dano resultante ou que tenha surgido em função de qualquer incidente ou acidente relacionado ao evento. O Estado é, nada mais, que um fiador (polpudo) da FIFA.

Ainda na circunscrição da Copa do Mundo, também chama a atenção o PL 728/2011, apresentado no Senado e que cria oito tipos penais que não constam no Código Penal brasileiro, como "terrorismo", "violação de sistema de informática" e "revenda ilegal de ingressos". A justificativa da proposta é a de "incrementar e garantir a segurança durante os jogos", dessa forma, então se amplia a policialização do Estado. Por fim, essa legislação de exceção pretende restringir as greves durante o período dos jogos, por se "constituir em abuso do direito de greve" e ainda permite que o governo contrate trabalhadores substitutos para manter o atendimento, o que é proibido pela lei vigente no país.

No que tange aos Jogos Olímpicos, um exemplo recente foi 0 encaminhamento de um projeto de lei pelo Prefeito Eduardo Paes que altera os parâmetros ambientais e urbanísticos da região da Barra da Tijuca, a fim de viabilizar a construção do campo de golfe. O campo se estenderá a uma distância de um milhão de metros quadrados numa área de proteção ambiental. A obra tem pretensão de ser executada por uma Parceria Público-Privada que reunirá diversos investidores imobiliários e que, além do campo de golfe, construirão blocos de apartamentos sob a propaganda de que terão "vista para o maior campo de golfe do Brasil" e ainda receberão como benesse a alteração do gabarito de 12 para 18 andares para construção de edificações na região do Parque Olímpico ${ }^{13}$.

Esses dispositivos jurídicos conferem forma concreta à "acumulação por espoliação", tal como definido por David Harvey e, gradativamente, vão moldando

\footnotetext{
${ }^{13}$ MAGALHÃES, Luiz Ernesto. Uma tacada polêmica. O Globo, Rio, p. 9, publicado em 2 nov. 2012. MAGALHÃES, Luiz Ernesto. Pacote altera gabarito no Parque Olímpico. O Globo, Rio, p. 10, publicado em 2 nov. 2012.
}

TrabalhoNecessário - www.uff.br/trabalhonecessario; Ano 11, № 16/2013. 


\section{Trabalhonecessário}

Issn: 1808 - 799X

ano 11, no $16-2013$

o evento a fim de garantir o pleno controle sobre todas as esferas públicas, incluindo o próprio espaço urbano, que, para se adequar a todos os requisitos, está se construindo um quadro chamado por Carlos Vainer como "cidade de exceção". Inspirado nas ideias de Giorgio Agamben sobre o "Estado de exceção", Vainer (2011) argumenta que existiria um "estado de emergência permanente" que autoriza a promulgação de medidas excepcionais a todo instante, a fim de que o poder público consiga levar adiante o projeto de cidade, tendo como mote a realização dos megaeventos. Assim, a cidade dos megaeventos acaba se constituindo nas "cidades ad hoc".

As cidades "ad hoc" não precisam de regras e princípios gerais, eles são acomodados para dar conta de cada situação específica, mesmo que em alguns casos ocorram violações dos direitos humanos, o que tem sido frequentemente denunciado por movimentos sociais organizados em torno da causa, resultando em dossiês que relatam toda série de arbitrariedades cometidas em nome da celeridade e do sucesso dos megaeventos.

A faceta mais evidente é a remoção de moradores dos seus locais de habitação. Segundo o dossiê "Megaeventos e violações de direitos humanos no Brasil", pelo menos 170 mil pessoas serão afetadas pelas medidas levadas adiante pelas prefeituras locais. Em todo o país, imperam a falta de debates públicos, transparência nas ações, a agressividade e a celeridade com que são tratados os moradores de regiões pauperizadas. Há diversas denúncias de ações de ordem de despejo imediato, pichações marcando os muros das casas a serem desapropriadas e incêndios criminosos contra as comunidades que insistem em resistir. No caso particular do Rio de Janeiro, evidencia-se o caráter excludente e classista do evento ao prever diversas medidas que visam remover os pobres da vista do espaço urbano em que haja maior circulação de pessoas. Quando removidas, as pessoas nem sempre são alocadas nas redondezas onde já fixaram suas raízes e organizaram suas vidas, mas nos bairros periféricos em que

TrabalhoNecessário - www.uff.br/trabalhonecessario; Ano 11, № 16/2013. 


\section{Trabalhonecessário}

Issn: 1808 - 799X

ano 11, no $16-2013$

se concentra o programa habitacional "Minha casa, minha vida", mas que não estão cobertas pelas melhorias na infraestrutura urbana, tal como nas localidades de realização das competições.

Emblemático mencionar o caso da Vila Autódromo, na região onde será instalada a maior parte das competições dos Jogos Olímpicos. A área é cobiçada por empreiteiras e grupos do ramo imobiliário devido a alta valorização que está em curso nos últimos anos. A remoção de mais de 500 famílias abriria um terreno significativo para empreendimentos destinados ao alto padrão de consumo que abrange a região. Desde a época dos Jogos Pan-Americanos, a comunidade é ameaçada pela Prefeitura e ainda resiste por meio de mobilizações políticas e liminares na Justiça que impede sua remoção. A Prefeitura promete a remoção no início de 2014.

Outra localidade muito importante no Rio de Janeiro e também alvo de remoções com caráter duvidoso é o Morro da Providência. Situado na região portuária da cidade e que vem recebendo grandes somas de investimento por parte do consórcio público-privado que administra o local, serão erguidos prédios que receberão as delegações de jornalistas e pessoal de apoio para os Jogos Olímpicos de 2016. Somados esses investimentos, pretende-se promover a região um ponto turístico devido à sua riqueza de sítios históricos, com a construção de um teleférico e um plano inclinado, estímulo a abertura de serviços de alto padrão que possam atender a turistas com maior recurso financeiro. Assim, a comunidade ainda se vê imersa de tensão e falta de informação, já que a Prefeitura alega que mais de 800 famílias terão de ser reassentadas a despeito dessas intervenções.

Dentro desse conjunto de medidas realizadas para os megaeventos esportivos, a geração de empregos é uma das justificativas mais divulgadas pelo governo para convencer a opinião pública sobre algum benefício para sua realização. Só que refletindo a situação do mundo do trabalho na 


\section{Trabalhonecessário}

Issn: 1808 - 799X

ano $11, \mathrm{n}=16-2013$

contemporaneidade, as obras desses empreendimentos também são marcados por terceirizações e quateirizações, precarização das condições de segurança do trabalho, desrespeito às leis vigentes, uma forte pressão para a celeridade das obras e ofensiva contra as organizações sindicais que atuam para impedir os abusos e reivindicar melhores patamares de remuneração.

Greves e manifestações dos operários das obras nos estádios da Copa do Mundo ocorreram em algumas cidades. No caso específico do Maracanã, houve duas paralisações em 2011. A primeira, no mês de agosto, motivada por um acidente que feriu gravemente um funcionário, o que irrompeu numa paralisação reivindicando o aumento do vale-refeição, plano de saúde, aumento salarial para alguns operários que ganhavam abaixo dos outros e melhores condições de segurança para o exercício das funções. A segunda aconteceu um mês depois, devido ao descumprimento do acordo. Os trabalhadores saíram às ruas e conseguiram chamar bastante a atenção da sociedade e da grande imprensa, que, por sinal, cumpriu seu recorrente papel de alarmar a população quanto ao não-cumprimento dos prazos e o dano à imagem do país ${ }^{14}$. Por fim, no dia 16 de setembro, após 16 dias de paralisação das atividades, o Tribunal Regional do Trabalho julgou como abusiva a greve, sob o argumento de que o sindicato deveria ter comunicado sua intenção à empresa com dois dias de antecedência após a realização de uma assembleia geral e que o acordo, embora descumprido pela empresa, ainda estaria vigente (COMITÊ POPULAR DA COPA E DAS OLIMPÍADAS DO RIO DE JANEIRO, 2012). Esse caso foi emblemático por representar a luta de parcela dos cidadãos comuns e mais simples que, mesmo

\footnotetext{
${ }^{14}$ Dois exemplos: CASADO, André. Contramão do Maraca: maioria dos operários das sedes está satisfeita. o Globo online, disponível em http://globoesporte.globo.com/futebol/copa-domundo/noticia/2011/09/contramao-do-maraca-maioria-dos-operarios-das-sedes-esta-satisfeita.html, acesso em 14 set. 2011.

MANSUR, Carlos Eduardo. À sombra da greve e do atraso pelo país. O Globo, Esporte, p. 4-5, publicado em 16 set. 2011.
} 


\section{Trabalhonecessário}

Issn: 1808 - 799X

ano $11, \mathrm{n}=16-2013$

organizados, tem contra si, inúmeras cadeias e grilhões que protegem a parcela privilegiada da sociedade capitalista.

Por fim, também cabe menção ao aspecto da segurança pública. Tendo em vista que esses megaeventos contam com farta presença de autoridades, atletas de renome internacional, turistas e jornalistas de todo o mundo, a preocupação com a proteção desse contingente excedente de pessoas, visa garantir que a credibilidade do país não seja abalada para a opinião pública mundial, especialmente por conta das reportagens veiculadas sobre a cidade que, por muitas vezes, mostrou o caos, a desordem e a violência urbana imperando no cotidiano. Mais do que a segurança em si, o que deveria ser tomado como objeto de profundos debates, o importante, neste caso, parece ser a transmissão de uma imagem de segurança, algo que encarne uma sensação de tranquilidade e proteção.

Particularizando o caso do Rio de Janeiro, é possível apontar que a política de segurança pública tem se voltado em priorizar uma ocupação ostensiva do espaço urbano que esteja circunscrito à infraestrutura relacionada aos megaeventos esportivos, a circulação de mercadorias e a presença dos turistas. Também pode se argumentar que o investimento maciço em aparatos de segurança, além de não corresponderem plenamente à expectativa dos cidadãos de preservação e circulação da vida pública, está intimamente ligado ao abastecimento do mercado da indústria bélica e da segurança privada. As informações dão conta de que se pretende gastar $R$ \$ 80 milhões em câmeras de monitoramento nos estádios, fora aquelas que já estão sendo instaladas nas vias públicas, fora um contrato de exclusividade com o fabricante de armas austríacas Glock para ser a "marca" oficial dos Jogos Olímpicos, ou seja, tem se evidente que os megaeventos esportivos alimentam uma indústria global de segurança (COMITÊ POPULAR DA COPA E DAS OLIMPÍADAS DO RIO DE JANEIRO, 2012).

TrabalhoNecessário - www.uff.br/trabalhonecessario; Ano 11, № 16/2013. 


\section{Trabalhonecessário}

Issn: 1808 - 799X

ano 11, no $16-2013$

\section{CONCLUSÃO}

Dentro desse quadro, podemos afirmar que a realização dos megaeventos esportivos na nova geografia mundial esportiva tem atendido à busca de alocação aos excedentes de capital, utilizando de artíficios espoliativos ao interesse público para viabilizar os eventos.

Tendo em vista que "o capital busca perpetuamente criar uma paisagem geográfica para facilitar suas atividades" (HARVEY, 2005, p.87), a ordenação espaço-temporal do capital organiza o destino para que esse capital represado entre em seu circuito lucrativo, evitando assim que se desvalorize. O capital prossegue em sua busca por mercados atrativos e, quando o encontram, seu problema de sobreacumulação é aliviado em curto prazo.

A acumulação por espoliação age como um ingrediente que combina elementos de coerção e persuasão, a fim de manter as relações desiguais de poder do capital sobre o trabalho. A outrora acumulação primitiva foi adaptada ao patamar de monopolização sob o qual o capital opera nos tempos atuais, a fim de 


\section{Trabalhonecessário}

Issn: 1808 - 799X

ano 11, no $16-2013$

continuar a extrair recursos e se apossar de ativos para a obtenção de sua expansão lucrativa. Acirra-se, desta forma, a concorrência por lucros cada vez mais altos e por novas formas de monopolizar setores da produção liberando, assim, um conjunto de ativos a um custo muito baixo. Desta forma, o capital sobreacumulado no mercado, ao se apossar desses ativos, irá impingir-lhes, imediatamente, um uso lucrativo ganhando a dianteira na corrida intramonopólios. E a "Cidade Maravilhosa" será maravilhosa apenas para alguns... poucos privilegiados.

\section{REFERÊNCIAS}

BARAN, Paul. A economia política do desenvolvimento, 4를 Ed, Rio de Janeiro: Zahar Editores, 1977.

COMITÊ POPULAR DA COPA E OLIMPÍADAS DO RIO DE JANEIRO. Megaeventos e violações dos direitos humanos no Rio de Janeiro, 2012.

HARVEY, David. O enigma do capital. São Paulo: Boitempo, 2011.

. O novo imperialismo, $2^{\mathrm{a}}$ ed, São Paulo, Loyola, 2005.

LÊNIN, Vladimir llitch. O imperialismo: fase superior do capitalismo. $4^{a}$ ed, São Paulo, Centauro, 2008. 


\section{Trabalhonecessário}

Issn: 1808 - 799X

ano 11, no $16-2013$

MASCARENHAS, Gilmar. Nada de novo na geografia carioca, Democracia Viva, Rio de Janeiro, Ibase, n. 35, p. 47-50, jun. 2007.

MÉSZÁROS, István. Para além do capital. São Paulo: Boitempo, 2002.

NAME, Leo; GOMES, Elisa S.; MONTEZUMA, Rita de Cássia M. A Copa do Mundo, as Olimpíadas e o PEU das Vargens: sobre estratégias discursivas e a produção de riscos pela legislação. In: Conferência Internacional Megaeventos e a Cidade, 2010, Niterói. Anais...., Niterói, 2010.

PENNA, Adriana. Megaeventos esportivos: novo templo do capitalismo contemporâneo. In: Conferência Internacional Megaeventos e a Cidade, 2010, Niterói. Anais..., Niterói, 2010.

SÁNCHEZ, Fernanda. A reinvenção das cidades na virada do século: agentes, estratégias e escalas de ação política. Revista de Sociologia e Política, Curitiba, n. 16, p. 31-49, jun. 2001.

VAINER, Carlos. Cidade de exceção: reflexões a partir do Rio de Janeiro. In: Encontro Nacional da ANPUR, 2011, Rio de Janeiro. Anais..., Rio de Janeiro, 2011.

Data de recebimento: 27/02/2013

Data de aprovação 25/03/2013

TrabalhoNecessário - www.uff.br/trabalhonecessario; Ano 11, № 16/2013. 